\title{
TXK wt Allele
}

National Cancer Institute

\section{Source}

National Cancer Institute. TXK wt Allele. NCI Thesaurus. Code C162445.

Human TXK wild-type allele is located in the vicinity of $4 \mathrm{p} 12$ and is approximately $68 \mathrm{~kb}$ in length. This allele, which encodes tyrosine-protein kinase TXK protein, is involved in tyrosine phosphorylation. 